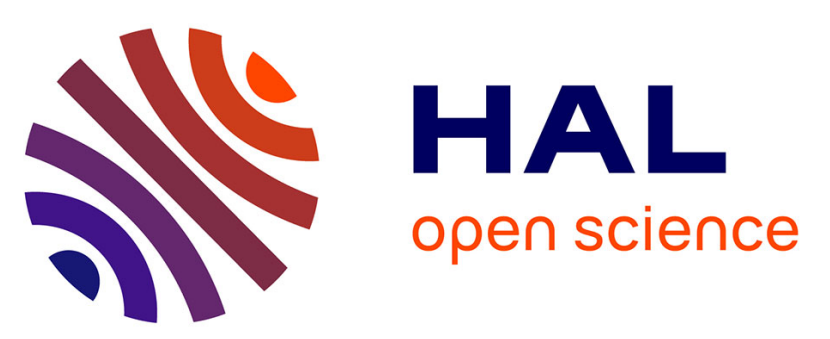

\title{
Embryological development of the freshwater crab Esanthelphusa nani (Naiyanetr, 1984) (Brachyura: Gecarcinucidae) using confocal laser scanning microscopy
}

Rachata Maneein, Camille Martinand-Mari, Julien Claude, Jirarach Kitana, Noppadon Kitana

\section{To cite this version:}

Rachata Maneein, Camille Martinand-Mari, Julien Claude, Jirarach Kitana, Noppadon Kitana. Embryological development of the freshwater crab Esanthelphusa nani (Naiyanetr, 1984) (Brachyura: Gecarcinucidae) using confocal laser scanning microscopy. Journal of Crustacean Biology, 2020, 40 (2), pp.162-171. 10.1093/jcbiol/ruaa002 . hal-02942293

\section{HAL Id: hal-02942293 \\ https://hal.umontpellier.fr/hal-02942293}

Submitted on 25 Nov 2020

HAL is a multi-disciplinary open access archive for the deposit and dissemination of scientific research documents, whether they are published or not. The documents may come from teaching and research institutions in France or abroad, or from public or private research centers.
L'archive ouverte pluridisciplinaire HAL, est destinée au dépôt et à la diffusion de documents scientifiques de niveau recherche, publiés ou non, émanant des établissements d'enseignement et de recherche français ou étrangers, des laboratoires publics ou privés. 


\title{
Embryonic development of the freshwater crab Esanthelphusa nani (Naiyanetr, 1984) (Gecarcinucidae) \\ Rachata Maneein ${ }^{1}$, Camille Martinand-Mari ${ }^{2}$, Julien Claude $^{2}$, Jirarach Kitana $^{1}$, and Noppadon Kitana ${ }^{1, *}$ \\ ${ }^{1}$ Department of Biology, Faculty of Science, Chulalongkorn University, Bangkok, Thailand \\ ${ }^{2}$ ISEM, Université de Montpellier, CNRS, IRD, EPHE, Montpellier, France \\ Correspondence: N. Kitana ${ }^{1}$; email: noppadon.k@chula.ac.th
}

\begin{abstract}
This study aims to investigate the embryonic development of Esanthelphusa nani, a common rice field crab found in paddy fields of northern Thailand, using confocal laser scanning microscopy. We found that the development of $E$. nani can be achieved in eggs within 12 days resulting in a hatchling stage corresponding to megalopa stage. Pre-organogenetic stages were characterized by a superficial cleavage including egg-cleavage, egg-blastula and egg-gastrula. Organogenesis stages were identified by appendage appearances and can be divided into egg-nauplius, egg-zoea and egg-megalopa. After hatching, crabs metamorphose to juveniles. By providing new comparative data, our study shed some new light on the relationship between environment, phylogeny and development; and opens potential area of research in an eco-evo-devo perspective.
\end{abstract}

Key Words: Primary freshwater crab, confocal microscope, ecological transition, developmental biology 


\section{INTRODUCTION}

One fundamental aspect of eco-evo-devo is to understand how ecology may interact with development and evolution and how phylogenetic history and development may constrain ontogenies (Gould, 1977; Gilbert \& Epel, 2015). The evolutionary transition between environments is particularly interesting in this respect. The aquatic-terrestrial transition in vertebrates is a well-known example. The amniotic egg in the higher vertebrate is a developmental innovation that allowed that transition and that is accompanied by remarkable changes in the early ontogeny (Sumida \& Martin, 1997). While we know relatively well the development of land and aquatic arthropods, we know less the different steps of evolutionary change during that transition. Crustaceans and crabs in particular, however, offer the possibility to understand that transition from a comparative point of view because they evolved iteratively to freshwater and the continental environment from marine forms (Jagt et al., 2015). On the other hand, crab development is well documented for marine groups, but the ontogeny of terrestrial and freshwater forms has been less studied.

The infraorder Brachyura (True crabs) is an extremely diversified group with 7,000 species (Cumberlidge \& Ng., 2009); they can be classified into three major ecological groups: marine, secondary freshwater and primary freshwater crabs. Marine crabs spend all their life and development in the sea, secondary freshwater crabs or "partly freshwater crabs" start their larval development in the sea and migrate later in their growth on land, and primary freshwater crabs or "wholly freshwater crabs" do their entire development on land ( Vogt, 2013; Yeo et $a l ., 2014)$. In this group, the development is largely modified, with direct development, production of fewer eggs and occurrence of parental care. As a consequence, some crabs of this group can become fully terrestrial (Vogt, 2013). The ontogenetic sequence has been documented in most ecologic and taxonomic groups. A simplified phylogeny derived from the work of Tsang et al. (2014) is provided in Fig. 1. Primitive marine crabs (Raninidae) present more than six zoea stages and one megalopa stage (Minagawa \& Murano, 1993). Eu-marine crabs (e.g., Portunidae, Grapsidae, Epialtidae, etc.) have 4-6 zoea stages and one megalopa stage (Dornelas et al., 2004; Islam et al., 2005; Oh \& Sook Ko, 2010). At least five families evolved as secondary freshwater crabs (Gecarcinidae, Varunidae, Sesarmidae, Pinnatheridae and some Chasmocarcinidae) and their development is very similar to eu-marine crab with zoea and megalopa stages (Cuesta et al., 2007; Kornienko et al., 2008; Cuesta et al., 2011). However, an abbreviation of larval development (with a reduction of stage number) has been documented in some of these secondary freshwater crabs (Bolaños et al., 2005). Freshwater crabs have been classified into 5 families (Potamonautidae, Gecarcinucidae, Potamidae, 
Pseudothelphusidae, and Trichodactylidae) but their development has rarely been studied. This is mostly because the development is direct and hatchling already displays adult-like morphology (Ng et al., 2008). Pace et al. (1976) was probably the first to provide an idea of the embryonic development of these crabs in his study on the potamid crab Potamon edulis using histological sections. Later, Wu et al. (2010), Xue et al. (2010) and Xue et al. (2013) documented the ontogenetic sequence within the egg in the potamid crab Sinopotamon yangtsekiense using stereomicroscopy but could not identify several anatomical features linked to the earliest developmental stages. This kind of studies are nevertheless crucial for documenting and understanding the links between development, ecology and crab morphological evolution.

As said previously, primary freshwater crabs are diverse and the study of their development could shed important light on evolutionary transition in this group. In this context, we analyzed the development of a primary freshwater crab, the rice field crab Esanthelphusa nani of the Gecarcinucidae. This crab was firstly described based on specimens caught at Nan Province in Thailand (Naiyanetr, 1984). For the first time, the documentation of this freshwater crab will be carried out with both stereo and confocal imaging which provides a more detailed analysis of its direct development.

\section{MATERIALS AND METHODS}

\section{Egg sampling}

The material was obtained in the rice fields of the Lai-Nan sub-district, Wiang Sa district, Nan province, where the endemic species of the rice field crab, Esanthelphusa nani is present (location: 47Q 0686779, UTM 2047187). Agricultural activities on the site are mainly rice farming, with no history of herbicide use over the past 10 years (Jantawongsri et al., 2015).

Most of the ovigerous crabs were caught by digging in their hole in the soil of the rice fields during the gestation period, from early March to late April. The animals were transported and acclimatized in the laboratory (at Chulongkorn University Forest and Research station, Wiang Sa District, Nan Province, Thailand). The carapace width of each female crab was measured. Small plastic boxes $(20 \times 20 \times 15 \mathrm{~cm})$ were used to separate mothers from each other. The gestation season was recreated in the laboratory: The boxes were kept in dark, no food neither water was provided, only a water-saturated sponge was used to maintain high humidity in the boxes.

Daily egg sampling started the day after the specimens arrived at the laboratory; at a fixed time (08:00AM), 20 to 40 eggs per mother were randomly removed from the abdominal 
pouch. The collected eggs were fixed in $70 \%$ ethanol and kept in $1.5 \mathrm{~mL}$ tubes at room temperature until the imaging. On the last day of sampling, all remaining eggs or juveniles were removed from the female pouch and included in order to appraise the total eggs for each clutch.

\section{Fluorescence staining}

For each stage, ten randomly collected eggs were first examined and the larval stages were digitally recorded using a stereomicroscope. The size of the eggs was measured according to the digital image. Until the fifth day of development after spawning, all eggs were observed with their envelope. After the $5^{\text {th }}$ day of development, the embryo being located on the condensed egg yolk allowed the envelope to be removed, improving observations. The embryos were rehydrated in 50\% ethanol for $30 \mathrm{~min}$, then in $25 \%$ ethanol for $30 \mathrm{~min}$ and finally in phosphate buffered saline (PBS) for $30 \mathrm{~min}$. The rehydrated eggs were fixed in $4 \%$ paraformaldehyde for $30 \mathrm{~min}$ then stained with $0.001 \%$ TRITC (Tetramethylrhodamine isothiocyanate, Sigma Aldrich) for one hour to deliver fluorescence in the embryo.

\section{Confocal microscope observation}

The samples were analyzed with a Leica TCS-SPE confocal laser microscope (Montpellier RIO Imaging platform, France) to acquire three-dimensional data represented by stacks of images: a $1 \mu \mathrm{m}$ step between each image (4 frames/image) for acquisition of about $200 \mu \mathrm{m}$ thick. The staining and confocal observation were reproduced three times for each studied stage.

\section{RESULTS}

Rice field crabs were able to produce egg clutches ranging from 300 to 600 eggs $(N=30)$. Egg size varied among individuals, with an average diameter of about $1.34 \pm 0.27 \mathrm{~mm}(N=120)$. The appearance of the egg was ball-shaped and yellowish in color, indicating an extreme quality of egg yolk and classifying it as a polylecithal type egg.

\section{Stage 1 egg-cleavage (Within 1 day of incubation; Fig. 2.1)}

The day after the night when the ovigerous crabs released their eggs, a pattern of superficial cleavage was noted in E. nani egg. At that time, many potential embryonic cells migrated under the shell membrane, indicating a late superficial cleavage (in this study, we could not isolate an earlier stage). The cleavage did not show cytokinesis giving several nuclei within the cytoplasm that can be considered as energids (Scholtz \& Wolff, 2013). Thus, the energids correspond to the potential embryonic cells in this study. The egg yolk is fragmented into very fine droplets. 
Stage 2 egg-blastula (At 2 days of incubation; Fig. 2.2)

The obvious presence of the blastopore on one side of the edge of the egg certifies the blastula stage. Potential embryonic cells have begun to group together delimiting different cell groups. The cytosol started to be isolated under the shell membrane. The egg yolk is divided in slightly larger droplets.

Stage 3 initial egg-gastrula (At 3 to 4 days of incubation; Fig. 2.3)

Individual cell membranes form at that stage. The first signs of a papilla positioned in the lateral-ventral position are observed (animal pole). It can be assumed that the cells of the blastula of the previous stage epibolically migrated from the surface of the egg to animal pole.

Stage 4 egg-gastrula (At 4 days of incubation; Fig. 2.4a and 2.4b)

The invagination of embryonic cells in the surrounding yolk forms a V-shaped papilla of cells. Drafts of the main embryonic cell groups (ocular, thoracic-abdominal and cephalic), all located ventrally, can already be seen. The labrum region, or the Hensen node or anterior primitive node, is located at the center of the invagination and the caudal region is connected to the primitive line resulting from the invagination. A few hours after the end of the egg-gastrula stage, the embryo has a protonauplius aspect (Fig. 3.1).

Stage 5 egg-protonauplius (At 4-5 days of incubation; Fig. 3.1)

This "protonauplius" is characterized by a rudimentary caudal papilla. This stage corresponds to the transition between pre-organogenesis to organogenesis stages. On either side of the invagination zone, an accumulation of cells becomes visible, so that the embryo is clearly identifiable on the surface of the yolk. From this stage, we removed the egg membrane to obtain better images. The rudiments of paired plates are increasing in relative size, thanks to cell proliferation, and unite to form an unpaired structure symmetrical to the longitudinal axis of the embryo (Fig. 3.1).

Stage 6 egg-nauplius (At 5 days of incubation; Fig. 3.2)

Thereafter, all the characters of the egg-nauplius stage are visible with the appearance of the first appendage primordia: a pair of buds of antennules, antenna and mandibles. This cluster corresponds to the first group of appendages of the head, specific to the embryonic development of crustaceans (Scholtz, 2000). The cells of the labrum region concentrate resulting in a labrum bud. Tiny structures positioned behind the ocular lobes are observed 
growing in the cephalic primordia. The mass of egg yolk moved and concentrated in the center of the egg, leaving space for further larval development.

Stage 7 egg-meganauplius (At 6 days of incubation; Fig. 3.3)

The rudimentary optical lobes enlarge and diverge from each other. The thoracic appendages and segments are now visible. In addition to the paired naupliar appendages, the branchiostegal appendages, i.e. the first and second maxillae and the three maxillipeds, appear. Beside the branchiostegal appendages, a pair of branchiostegal folds are visible. The caudal papilla is segmented and presents the terminal duct of the intestine with the anus at its tip. Its folding covers part of the anterior region up to the level of the second maxillae

Stage 8 early egg-zoea like (At 7 days of incubation; Fig. 3.4)

The appendages are much larger, and the branchiostegal ones begin to duplicate the second branchiostegal buds. Branchiostegal folds grow on both sides to the posterior part of the embryo. The pairs of appendages of the legs split out from the caudal papilla.

\section{Stage 9 late egg-zoea like (At 7-8 days of incubation; Figs. 4.1a-e)}

The optical lobes reveal the eyestalk character (Fig. 4.1b). After the separation of the last pair of leg appendages from the caudal pillar, the rest of the caudal pillar appears as the true abdominal plate. The branchiostegal appendages are fully duplicated, and the 10 pairs can be considered as the final exopods. The rudimentary shell began to develop as embryonic cells migrated to the posterior part of the embryo and expanded from both sides of the branchiostegal folds.

Stage 10 early egg-megalopa like (At 8 days of incubation; Figs. 4.2a-e)

The antennules and antenna, the mandibles and maxillae become relatively smaller than the posterior thoracic limbs, which develop at a faster rate. The folding of the caudal papilla now only covers the part of the anterior region where the future legs are located (Fig. 4.2b). The major event at this stage is the formation of the shell. The dorsal view of the egg clearly shows the dorsal shell line and the rudimentary shell plates on the left and right and posterior sides (Fig. 4.2d).

Stage 11 egg-megalopa like (At 9 days of incubation; Figs. 5.1a-e)

The compound eyes are now pigmented. The distinct plates of the shell have fused to form a single shell plate that surrounds most of the cephalo-thoracic viscera. Some duplicated 
branchiostegal buds disappear, some of them even fold back. The first walking-legs have grown and their tips display a scissor-like shape.

Stage 12 late egg-megalopa like (At 10-11 days of incubation; Figs. 5.2a-e, 5.3a-e)

These stages occurs about 2-3 days before hatching. Eyestalks, antennules, antennae, and mandibles are fully developed. All the organs are fully formed and ready to perform their function. The main event at this stage is the increase in size of the embryo.

\section{Stage 13 hatching megalopa like (At 12 days of incubation; Figs. 6.1a-e)}

At hatching, the cuticle is fully formed. As a result, TRITC staining could not reach the embryo. Stereomicroscope images replace confocal microscope ones. The overview characters of the hatching stage are very similar to those of the previous stage. The shell is covered with a translucent membrane, which is supposed to protect the soft shell. At hatching, the average carapace size of the megalopa was $1.375 \pm 0.093$ wide and $1.357 \pm 0.141 \mathrm{~cm}$ long and that of the cepahalothorax deep was $1.401 \pm 0.150 \mathrm{~cm}(N=24)$.

\section{Stage 14 juvenile crab (At 12 days of incubation; Figs. 6.2a-e)}

A few hours after hatching, the megalopa larvae metamorphosed into a juvenile crab. The shape of the juvenile carapace has widened compared to that of the megalopa carapace due to the absence of the physical constaints generated by egg menbrane. The five pairs of branchiostegal appendages were transformed into five pairs of mouthparts. The first pair of walking legs develops like a pair of chelae. The average carapace size of the first juvenile was $1.422 \pm 0.176$ $\mathrm{cm}$ wide and $1.361 \pm 0.126 \mathrm{~cm}$ long and that of the cepahalothorax deep was $1.151 \pm 0.158 \mathrm{~cm}$ $(N=24)$.

\section{DISCUSSION}

This study is the first one using confocal microscopy to document crab development. In the case of primary freshwater crab, this technology allowed to deal with the insufficient resolution offered by stereomicroscope. It was particularly relevant for the part of the development occurring within the egg since primary freshwater crabs have direct development contrary to other crabs for which early stages are free-living and can be easily observed. The use of confocal microscopy was facilitated by the development of the crab which follows a superficial cleavage development, exposing the embryo close to the surface of the egg.

Table 1 shows comparisons among crabs for which the embryonic development is known. Our study is the first one looking at the ontogenetic sequences of primary freshwater crabs of the family Gecarinucidae. It further documents the development of primary freshwater 
crabs at a broader taxonomic scale. Former studies have focused on primary freshwater crabs of the family Potamidae (Pace et al., 1976; Wu et al., 2010; Xue et al., 2010; Xue et al., 2013). Sinopotamon yangtsekiense (Potamidae) has completed larval development since in an egg (nauplius, zoae, megalopa, and juvenile stages) and hatchs as a juvenile crab (Wu et al., 2010; Xue et al., 2013). Those development stages of S. yangtsekiense are similar to Potamon edulis (Potamidae). Among the crabs studied, the development of Esanthelphusa nani (Gecarinucidae) produced hatchlings at megalopa stages. A few hour after hatching, it metamorphoses to be a juvenile crabs within a much shorter development (12 days) by comparison to the two other ones that were documented (77 days for S. yangtsekiense and 4647 days for P. edulis) (Pace et al., 1976; Wu et al., 2010). Whether the shortened development and the hatchling at megalopa stage is typical of E. nani or of the Gecarcinucidae clade should be documented by observations in other species within Potamidae, Potamonautidae and Gecarcinucidae. It would be particularly interesting to polarise these characters in the phylogeny in order to understand whether they are linked to terrestrialisation. The fast development of $E$. nani is certainly an advantage in anthropized and non permanent habitat such has rice fields. This has also impact for understanding how to control populations in agricultural area because, theoretically, several episodes of reproductions are likely within a single season warranting the survival of the species.

As in other primary freshwater crabs, the development is direct. Therefore, the crab does not have free nauplius, zoea, or free early megalopa stages. We were, however, able to find similarities with those stages based on the developmental sequences of appendages as in the work of Pace et al. (1976) and Wu et al. (2010).

The development of the embryo of E. nani is superficial and can be classified in the superficial cleavage model. It is similar with the development of most land arthropods such as the land isopod Porcellio scaber (Wolff, 2009) or the land anomuran Aegla platensis (LizardoDaudt et al., 2003). Cleavage is limited by a massive yolk mass in the center that confines mobile cleavage cells to the cytoplasmic edge of the egg (Schetelig et al., 2007; Eriksson \& Tait, 2012). Furthermore, there are no partitions and no cell membranes delimiting cells in the early development as for the coenocytic blastoderm of some other terrestrial arthropods (Fig. 1.1). By contrast, early total cleavage can be present in secondary freshwater crabs as in the mitten crab Eriocheir japonica (Varunidae) or in marine crabs such as the fiddler crabs Uca lacteal (Ocypodidae) (Kobayashi \& Matsuura, 1995; Yamaguchi, 2001). Interestingly the modes of cleavage do not necessarily express a strong relationship with arthropod phylogeny (Peterson \& Eernisse, 2001; Scholtz \& Wolff, 2013) but might be related to yolk mass quantity, 
which itself may relate with the ecology. Further exploration at the infra-order or suborder level would be interesting in that respect.

Early in the development, the "egg nauplius" stage showed obvious naupliar appendages with no segmentation (antennule, antenna and mandible appendages that are associated with neurology and myology). This part of development is preserved among Eumalacostraca (Scholtz, 2000; Vogt, 2013). but also present outside of the Eumalacostraca since it is also reported in Pleocyemata, a member of decapods (Jirikowski et al., 2013).

At later stages, unlike the marine crab, post-nauplius stages of the primary freshwater crab form within the eggs. The transition between larval stages of the primary freshwater crab seems to be more continuous (without molting) and more difficult to categorize than those of the marine crab. In general, free-living zoae stages are characterized based on characters of maxillipeds, pereiopods and pleopods (da Silva et al., 2012; Magalhães et al., 2017). When compared with marine crabs (for instance Xanthoidea in (Clark, 2005), Table 1), zoea stages show differences in terms of appearance of setae, endopod and exopod on maxillipeds. Likely, these differences come from the fact that this appendage is not yet used for feeding or moving as in free-living zoea stage (Epelbaum \& Borisov, 2006). Pleopods of E. nani were not evidenced but might be hidden by their growth under the abdominal plate as the histologic section of Potamon edulis in zoea stage presented up to 8 thorax somites which relate to appendages under abdomen (Pace et al., 1976). Using of pereiopods should be noted as a suitable external character of larva for extricating stages of egg-zoae and egg-megalopa stages in crustacean with direct development such as the primary freshwater crab. The onset of appendage development differ greatly among crab lineages (Table 1). E. nani seems to be intermediary in terms of onset for appendage apparition by comparison to body shape development among documented freshwater crabs. It is delayed by comparison to $P$. edulis but accelerated by comparison to $S$. yangtsekiense. This difference does not seem to be associated with the rapid development of E. nani since it develop faster than the two potamid species. Further studies might be necessary to see whether development timings in Gecarinucidae is as variable as in Potamidae. We can eventually speculate that this disparity in freshwater crabs may greatly depend on the variety of terrestrial environment and to their degree of terrestrialisation.

Interestingly, we can notice that development timing is not necessarily linked to the ecological groups of crabs (primary freshwater, secondary freshwater and marine crabs). Also direct development is a characteristic of all freshwater crabs, the abbreviation of larval stages does not only occur in secondary freshwater crabs but in some marine crabs (e.g. S. acutifrons 
in Heterotremata). This convergent pattern might not be only related to main habitat ecology (Vogt et al., 2013), but to more specific ecological characteritics and life trait history related to the environment of the larva, which might have evolved to feed more directly like adults. By looking more in details at the sequence of appendage formation during abbreviated development, it is, however, possible to define characters that are related to phylogeny and others to habitat. In particular appendages shape and development may be affected by the environment where the larva evolved. Obviously, pereiopod and pleopod appendages of marine larva are different in shape from terrestrial species. Setae in free living larva of marine crab tends to be more numerous than the one developing in eggs, possibly due to the fact that this appendage is not yet used for feeding or moving as in free-living zoea stage (Epelbaum \& Borisov, 2006).

Although our study extended the knowledge about early development in primary freshwater crabs, it would be interesting to study other group of freshwater crabs to generalize our findings and to define further differences and similarities that could be phylogeny or ecology dependent in order to complete our comparison table. In particular, primary freshwater crabs are not monophyletic and this ecology might have evolved at least three times in the infra-order Brachyura (Fig. 1). So far the development have been described in three crabs of the clade containing Potamidae, Gecarcinucidae and Potamonautidae, but these groups may inherit their ecology and development from the common ancestor. It would therefore be interesting to compare differences and similarities with other freshwater clades such as Trichodactylidae or Pseudothelphusidae which are supposed to have independently evolved a primary freshwater morphology (Fig. 1). Furthermore, it would be important to document the developmental sequence in marine sister groups to be able to partition out which characters might be related to ecology and which one might relate to phylogeny. It would also be interesting to further compare the development among primary freshwater crabs that show various degrees of terrestrialisation and parental care to see how it might influence the morphology of the embryo at the different stages. Comparison with other groups could allow to understand convergent pattern in a more functional way. For instance, loss of free-living zoea stage is not unique to primary freshwater crabs but is known also in shrimps and is used to separate Palaemonidae and Atyidae (Jirikowski et al., 2013). Finally, documenting early stages of development in marine and secondary freshwater crabs within their eggs could improve our understanding of developmental timing, in particular in terms of appendage development. 


\section{ACKNOWLEDGEMENTS}

This research was supported by The $100^{\text {th }}$ Anniversary Chulalongkorn University Fund for Doctoral Scholarship, and Sponsorship for Graduate Student Research under CU Academic Network in the Region. We acknowledge the imaging facility MRI, member of the national France-BioImaging infrastructure supported by the French National Research Agency (ANR10-INBS-04, "Investments for the future"). We thank the French/Thai Bilateral Program in Higher Education and Research SIAM grant to support the travel for research in France. We also thank two anonymous reviewers for their constructive and insightful suggestions. 


\section{REFERENCES}

Anger, K., Schreiber, D., \& Montú, M. 1995. Abbreviated larval development of Sesarma curacaoense (Rathbun, 1897) (Decapoda: Grapsidae) reared in the laboratory. Nauplius, 3: 127-154.

Bolaños, J., Rivero, W., Hernández, J. Magán, I., Hernández, G., Cuesta, J.A. \& Felder, D.L., 2005. Abbreviated larval development of the pea crab Orthotheres barbatus (Decapoda: Brachyura: Pinnotheridae) described from laboratory-reared material, with notes on larval characters of the Pinnotherinae. Journal of Crustacean Biology, 25: 500-506.

Clark, P.F. 2005. The evolutionary significance of heterochrony in the abbreviated zoeal development of pilumnine crabs (Crustacea: Brachyura: Xanthoidea). The Journal of the Linnean Society of London, 143: 417-446.

Cuesta, J.A., Schubart, C.D., \& Rodríguez, A. 2000. Larval development of Brachynotus sexdentatus (Risso, 1827) (Decapoda, Brachyura) reared under laboratory conditions, with notes on larval characters of the Varunidae. Invertebrate reproduction and development, 38: 207-223.

Cuesta, J.A., García-Guerrero, M.U. \& Hendrickx, M.E. 2007. The complete larval development of Johngarthia planatus (Brachyura: Grapsoidea: Gecarcinidae) described from laboratory reared material, with notes on the affinity of Gecarcinus and Johngarthia. Journal of Crustacean Biology, 27: 263-277.

Cuesta, J.A., Guerao, G., Schubart, C.D. \& Anger, K. 2011. Morphology and growth of the larval stages of Geograpsus lividus (Crustacea, Brachyura), with the descriptions of new larval characters for the Grapsidae and an undescribed setation pattern in extended developments. Acta Zoologica, 92: 225-240.

Cumberlidge, N., Fenolio, D.B., Walvoord, M.E. \& Stout, J. 2005. Tree-climbing crabs (Potamonautidae and Sesarmidae) from phytotelmic microhabitats in rainforest canopy in Madagascar. Journal of Crustacean Biology, 25: 302-308.

Cumberlidge, N. \& Ng, P.K. 2009. Decapod Crustacean Phylogenetics, vol. 18. In: Systematics, evolution, and biogeography of freshwater crabs. (Martin, J.W., Crandall, K.A. \& Felder, D.L., Eds), pp.491-508. CRC Press, Boca Raton, Florida, USA.

Dornelas, M., Clark, P.F. \& Paula, J. 2004. The larval development of Nanocassiope melanodactyla (A. Milne-Edwards, 1867) (Crustacea: Decapoda: Brachyura: Xanthidae). Journal of Natural History, 38: 509-535.

Epelbaum, A. \& Borisov, R. 2006. Feeding behaviour and functional morphology of the feeding appendages of red king crab Paralithodes camtschaticus larvae. Marine Biology Research, 2: 77-88.

Eriksson, B.J. \& Tait, N.N. 2012. Early development in the velvet worm Euperipatoides kanangrensis Reid 1996 (Onychophora: Peripatopsidae). Arthropod Structure \& Development, 41: 483-493.

Gilbert, S.F. \& Epel, D. 2015. Ecological developmental biology: the environmental regulation of development, health, and evolution. Sinauer Associates Inc., Sunderland, Massachusetts.

Gould, S.J. 1977. Ontogeny and phylogeny. Harvard University Press.

Islam, M.S., Machiko, K. \& Shokita, S. 2005. Larval development of the swimming crab Thalamita pelsarti Montgomery, 1931 (Crustacea: Brachyura: Portunidae) reared in the laboratory. Russian Journal of Marine Biology, 31: 78-90.

Jagt, J.W., van Bakel, B.W., Guinot, D., Fraaije, R.H. \& Artal, P. 2015. Treatise on ZoologyAnatomy, Taxonomy, Biology. The Crustacea, vol. 9C. In: Fossil Brachyura 
(Castro, P., Davie, P., Guinot, D., Schram, F. and Klein, C.V.V., Eds), pp. 847920. Brill, Leiden, the Netherlands.

Jantawongsri, K., Thammachoti, P., Kitana, J., Khonsue, W., Varanusupakul, P. \& Kitana, N. 2015. Altered Immune Response of the Rice Frog Fejervarya limnocharis Living in Agricultural Area with Intensive Herbicide Utilization at Nan Province, Thailand. EnvironmentAsia, 8.

Jirikowski, G.J., Richter, S. \& Wolff, C. 2013. Myogenesis of Malacostraca-the "eggnauplius" concept revisited. Frontiers in Zoology, 10: 76.

Kobayashi, S. \& Matsuura, S. 1995. Egg development and variation of egg size in the Japanese mitten crab Eriocheir japonicus (De Haan). Benthos Research, 46: 29-39.

Kornienko, E., Korn, O. \& Kashenko, S. 2008. Comparative morphology of larvae of coastal crabs (Crustacea: Decapoda: Varunidae). Russian Journal of Marine Biology 34, 77-93.

Lizardo-Daudt, H.M. \& Bond-Buckup, G. 2003. Morphological aspects of the embryonic development of Aegla platensis (Decapoda, Aeglidae). Crustaceana, 76: 1326.

Magalhães, T., Souza-Carvalho, E.A., Biagi, R., Cuesta, J.A. \& Mantelatto, F.L. 2017. Larval stages of the crab Mithrax tortugae (Brachyura: Mithracidae) with comparisons between all species of Mithrax. Marine Biology Research, 13: $1108-1117$.

Minagawa, M. \& Murano, M. 1993. Larval feeding rhythms and food consumption by the red frog crab Ranina ranina (Decapoda, Raninidae) under laboratory conditions. Aquaculture, 113: 251-260.

Naiyanetr, P. 1984. Two new species of Pu Na of Thailand. Abstracts of the 22nd Conference Fisheries Section, Kasetsart University. p. 14. Bangkok.

Ng, P.K.L., Guinot, D. \& Davie, P.J.F. 2008. Systema Brachyurorum: Part I. An annotated checklist of extant brachyuran crabs of the world. Raffles Bulletin of Zoology, 17: 1-286.

Oh, S.M. \& Sook Ko, H. 2010. Larval development of Scyra acutifrons (Crustacea: Decapoda: Epialtidae) with a key from the northern Pacific. Animal Cells and Systems 14, 333-341.

Peterson, K.J. \& Eernisse, D.J. 2001. Animal phylogeny and the ancestry of bilaterians: inferences from morphology and 18S rDNA gene sequences. Evolution \& Development, 3: 170-205.

Pace, F., Harris, R. \& Jaccarini, V. 1976. The embryonic development of the Mediterranean freshwater crab, Potamon edulis (= P. fluviatile) (Crustacea, Decapoda, Potamonidae). Journal of Zoology, 180: 93-106.

Sakai, K. 1971. The larval stages of Ranina ranina (Linnaeus) (Crustacea, Decapoda, Raninidae) reared in the laboratory, with a review of uncertain zoeal larvae attributed to Ranina. Seto Marine Biological Laboratory, 19(2-3): 123-156.

Schetelig, M., Horn, C., Handler, A. \& Wimmer, E. 2007. Area-Wide Control of Insect Pests. In: Development of an embryonic lethality system in Mediterranean fruit fly Ceratitis capitata (Vreysen, M.J.B., Robinson, A.S. \& Hendrichs, J., Eds), pp. 85-93. Springer, Dordrecht, the Netherlands.

Scholtz, G. 2000. Evolution of the nauplius stage in malacostracan crustaceans. Journal of Zoological Systematics and Evolutionary Research, 38: 175-187.

Scholtz, G. \& Wolff, C. 2013. Arthropod Biology and Evolution Moleceles, Development, Morphology. In: Arthropod embryology: cleavage and germ band development 
(Mineelli, A., Boxshall, G. \& Fusco, G., Eds), pp. 63-89. Springer, Heidelberg, Germany.

Scholtz, G. \& McLay, C.L. 2009. Decapod Crustacean Phylogenetics, vol. 18. In: Is the Brachyura Podotremata a monophyletic group (Martin, J.W., Crandall, K.A. \& Felder, D.L., Eds), pp.417-435. CRC Press, Boca Raton, Florida.

da Silva, U.A., Cottens, K., Ventura, R., Boeger, W.A. \& Ostrensky, A. 2012. Different pathways in the larval development of the crab Ucides cordatus (Decapoda, Ocypodidae) and their relation with high mortality rates by the end of massive larvicultures. Pesquisa Veterinária Brasileira, 32: 284-288.

Sumida, S. \& Martin, K.L. 1997. Amniote Origins: Completing the Transition to Land.pp. 265-290. Academic Press. San Diego, California, USA.

Tsang, L.M., Schubart, C.D., Ahyong, S.T., Lai, J.C., Au, E.Y., Chan, T.Y., Ng, P.K. \& Chu, K.H. 2014. Evolutionary history of true crabs (Crustacea: Decapoda: Brachyura) and the origin of freshwater crabs. Molecular Biology and Evolution, 31: 1173-1187.

Vogt, G. 2013. Abbreviation of larval development and extension of brood care as key features of the evolution of freshwater Decapoda. Biological Reviews, 88: 81116.

Wolff, C. 2009. The embryonic development of the malacostracan crustacean Porcellio scaber (Isopoda, Oniscidea). Development Genes and Evolution, 219: 545-564.

Wu, H. \& Xue, J., Cumberlidge, N. 2010. An extra embryonic phase in the true freshwater crab Sinopotamon yangtsekiense Bott, 1967 (Decapoda, Potamidae). Chinese Journal of Oceanology and Limnology, 28: 725-730.

Xue, J., Liu, Y., Cumberlidge, N. \& Wu, H. 2010. First report of developmental changes inside the eggs of the Chinese freshwater crab, Sinopotamon yangtsekiense Bott, 1967 (Potamoidea, Potamidae), with comments on its evolutionary significance. Contribution to Zoology, 79, 79-84.

Xue, J., Liu, Y., Cumberlidge, N. \& Wu, H. 2013. Changes during late-stage embryonic development from egg-juvenile to free-living hatchling in Chinese freshwater crab Sinopotamon yangtsekiense (Decapoda, Brachyura, Potamidae). Chinese Journal of Oceanology and Limnology, 31(3): 542-551.

Yamaguchi, T. 2001. Incubation of eggs and embryonic development of the fiddler crab, Uca lactea (Decapoda, Brachyura, Ocypodidae). Crustaceana, 74: 449-458.

Yeo, D.C.J., Cumberlidge, N. \& Klaus, S. 2014. Advances in Freshwater Decapod Systematics and Biology, Brill, Leiden. 


\section{List of Figures and Table}

Figure 1. Phylogenetic relationships between members of the brachyura family; modified tree based from analyses of genetic data sets by Tsang et al. (2014). The different color present the three major ecological lifestyles : primary freshwater, secondary freshwater and marine crabs. The circle marks on the tree are those families for which embryonic and larval development data are present in Table 1.

Figure 2. Confocal microscopic photographs representing E. nani embryos at preorganogenesis stages. 1: egg-cleavage; 2: egg-blastula; 3: initial gastrula; 4: gastrula with head (a) and tail (b) views. The upper images show the whole eggs while the lower ones show a double magnification of the upper images. A: antenna region; BP: blastopore; C: caudal papilla; E: embryonic cells; G: grouping of potential embryonic cell; L: labrum region; N: space without embryonic cell; O: optic region; PE: potential embryonic cells; Pr: primitive streak.

Figure 3. Confocal microscopic photographs representing E.nani embryos at organogenesis part 1. 1: egg-protonauplius; 2: egg-nauplius; 3: egg-metanauplius; 4: egg-early zoea. The upper images show the whole eggs while the lower ones show a double magnification of the upper images. An: antennule appendage; At: antenna appendage; b1-5: branchiostegal appendages; BF: branchiostegal fold; C: caudal papilla; L: pereiopod or walking leg; Lr: labrum M: mandibular appendage; O: optic lobe; Y: yolk.

Figure 4. Confocal microscopic photographs representing E.nani embryos at organogenesis part 2. 1a-e: egg-late zoea; 2a-e: egg-early megalopa. The upper images show the whole eggs while the lower ones show a double magnification of the upper images. A: abdomen; b1-5: branchiostegal appendages; BF: branchiostegal fold; C: caudal papilla; E: rudimentary eyes; ES: eyestalk; Ex: exopod-like; L1-5: pereiopod or walking leg; RC: rudimentary carapace; T: telson; Y: yolk.

Figure 5. Confocal microscopic photographs representing E.nani embryos at organogenesis part 3 including late stages (1a-e) egg-megalopa; ( 2 and 3 a-e: egg-late megalopa. The upper images show the whole eggs while the lower ones show a double magnification of the upper images (scale bars $=50 \mu \mathrm{m})$. A: abdomen; An: antennule; At: antenna; b4-5: 
branchiostegal appendages; C: carapace; CE: compound eye; ES: eyestalk; Ex: exopod-like; L1-5: pereiopod or walking leg M: mandible; R: rostrum; T: telson.

Figure 6. Stereomicroscopic photographs representing E. nani at hatching stages. 1a-e: hatching-megalopa; 2a-e: first instar juvenile. A: abdomen; At: antenna appendage; Bs: branchiostegal appendages; Ca: carapace; Ch: chela; Co: compound eye; ES: eyestalk; M3: third maxilliped; L1-5: pereiopod or walking leg; Ro: rostrum; T: telson.

Table 1. Comparison of morphological features of appendages/characters at embryonic/larval stages of Esanthelphusa nani [Gecarinucidae] from the present study; Sinopotamon yangtsekiense [Potamidae] by Wu et al. (2010); Potamon edulis [Potamidae] by Pace et al. (1976); Scyra acutifrons [Epialtidae] by Oh \& Sook Ko (2010); Nanocassiope melanodactyla [Xanthothidae] by Dornelas et al. (2004); Sesarma curacaoense [Sesarmidae] by Anger et al. (1995); Brachynotus sexdentatus [Varunidae] by Cuesta et al. (2000); Geograpsus lividus [Grapsidae] by Cuesta et al., (2011); and Ranina ranina [Raninidae] by Sakai (1971) 
Table 1. Comparison of morphological features of appendages/characters at embryonic/larval stages of Esanthelphusa nani [Gecarinucidae] from the present study; Sinopotamon yangtsekiense [Potamidae] by Wu et al. (2010); Potamon edulis [Potamidae] by Pace et al. (1976); Scyra acutifrons [Epialtidae] by Oh \& Sook Ko (2010); Nanocassiope melanodactyla [Xanthothidae] by Dornelas et al. (2004); Sesarma curacaoense [Sesarmidae] by Anger et al. (1995); Brachynotus sexdentatus [Varunidae] by Cuesta et al. (2000); Geograpsus lividus [Grapsidae] by Cuesta et al., (2011); and Ranina ranina [Raninidae] by Sakai (1971)

\begin{tabular}{|c|c|c|c|c|c|c|c|c|c|}
\hline Section/Subsection & \multicolumn{5}{|c|}{ Eubrachyura/Heterotremata } & \multicolumn{3}{|c|}{ Eubrachyura/Thoracotremata } & Raninoida \\
\hline Family & Gecarcinucidae & Potamidae & Potamidae & Epialtidae & Xanthothidae & Sesarmidae & Varunidae & Grapsidae & Raninidae \\
\hline Species & $\begin{array}{l}\text { Esanthelphusa } \\
\text { nani }\end{array}$ & $\begin{array}{l}\begin{array}{l}\text { Sinopotamon } \\
\text { yangtsekiense }\end{array} \\
\end{array}$ & Potamon edulis & Scyra acutifrons & $\begin{array}{l}\text { Nanocassiope } \\
\text { melanodactyla }\end{array}$ & $\begin{array}{l}\text { Sesarma } \\
\text { curacaoense }\end{array}$ & $\begin{array}{l}\text { Brachynotus } \\
\text { sexdentatus }\end{array}$ & Geograpsus lividus & Ranina ranina \\
\hline Habitats & $\begin{array}{l}\text { Rice field, } \\
\text { freshwater }\end{array}$ & River, freshwater & $\begin{array}{l}\text { Streams, } \\
\text { freshwater }\end{array}$ & Marine & Marine & Mangrove & Coastal to marine & Marine & Marine \\
\hline Type of development & $\begin{array}{l}\begin{array}{l}\text { Direct } \\
\text { development }\end{array} \\
\end{array}$ & $\begin{array}{l}\text { Direct } \\
\text { development }\end{array}$ & $\begin{array}{l}\text { Direct } \\
\text { development }\end{array}$ & $\begin{array}{l}\text { Abbreviated } \\
\text { development }\end{array}$ & Extended development & $\begin{array}{l}\text { Abbreviated } \\
\text { development }\end{array}$ & Extended development & Extended development & $\begin{array}{l}\begin{array}{l}\text { Extended } \\
\text { development }\end{array} \\
\end{array}$ \\
\hline Hatching stage & Megalopa & Juvenile & Juvenile & Zoea & Zoea & Zoea & Zoea & Zoea & Zoea \\
\hline $\begin{array}{l}\text { Total period of } \\
\text { embryonic/larva } \\
\text { development }\end{array}$ & 12 days in eggs & 77 days in eggs & $46-47$ days in eggs & Not available & 30 days after hatching & $\begin{array}{l}\text { 17-20 days after } \\
\text { hatching }\end{array}$ & $\begin{array}{l}17-22 \text { days after } \\
\text { hatching }\end{array}$ & 60 days after hatching & Not available \\
\hline Appendages/Characters & Onset at stages & Onset at stages & Onset at stages & Onset at stages & Onset at stages & Onset at stages & Onset at stages & Onset at stages & Onset at stages \\
\hline 1st ANTENNA & egg nauplius & egg nauplius & egg nauplius & Zoea1,Zoea2 (?) & Zoeal (?) & Zoea1,Zoea2 (?) & Zoea1,Zoea2 (?) & Zoea1-Zoea5 (?) & Zoea1-Zoea8 (?) \\
\hline 2nd ANTENNA & egg nauplius & egg nauplius & egg nauplius & Zoea1,Zoea2 (?) & Zoea1 (?) & Zoea1,Zoea2 (?) & Zoea1,Zoea2 (?) & Zoea1-Zoea5 (?) & Zoea1-Zoea8 (?) \\
\hline MANDIBLE & egg nauplius & egg nauplius & egg nauplius & Zoea1,Zoea2 (?) & Zoeal (?) & Zoea1,Zoea2 (?) & Zoea1,Zoea2 (?) & Zoea1-Zoea5 (?) & Zoea1-Zoea8 (?) \\
\hline MAXILLULE & egg metanauplius & egg zoea like & egg metanauplius & Zoea1,Zoea2 (?) & Zoea1 (?) & Zoea1,Zoea2 (?) & Zoea1,Zoea2 (?) & Zoea1-Zoea5 (?) & Zoea1-Zoea8 (?) \\
\hline MAXILLA & egg metanauplius & egg zoea like & egg metanauplius & Zoea1,Zoea2 (?) & Zoea1 (?) & Zoea1,Zoea2 (?) & Zoea1,Zoea2 (?) & Zoea1-Zoea5 (?) & Zoea1-Zoea8 (?) \\
\hline 1st MAXILLIPED & egg metanauplius & egg zoea like & egg metanauplius & Zoea1,Zoea2 (?) & Zoea1 (?) & Zoea1,Zoea2 (?) & Zoea1,Zoea2 (?) & Zoea1-Zoea5 (?) & Zoea1-Zoea8 (?) \\
\hline 2nd MAXILLIPED & egg metanauplius & egg zoea like & egg metanauplius & Zoea1,Zoea2 (?) & Zoeal (?) & Zoea1,Zoea2 (?) & Zoea1,Zoea2 (?) & Zoea1-Zoea5 (?) & Zoea1-Zoea8 (?) \\
\hline $\begin{array}{l}\text { 3rd MAXILLIPED } * * * \\
\text { 1st PEREIOPOD } * * *\end{array}$ & $\begin{array}{l}\text { egg metanauplius } \\
\text { egg zoea like }\end{array}$ & $\begin{array}{l}\text { egg megalop like } \\
\text { egg megalop like }\end{array}$ & $\begin{array}{l}\text { egg metanauplius } \\
\text { egg metanauplius }\end{array}$ & $\begin{array}{l}\text { Zoea1,Zoea2 (?) } \\
\text { Zoea1,Zoea2 (?) }\end{array}$ & $\begin{array}{l}\text { Zoea2,Zoea3,Zoea4 } \\
\text { Zoea2,Zoea3,Zoea4 }\end{array}$ & $\begin{array}{l}\text { Zoea1,Zoea2 (?) } \\
\text { Zoea1,Zoea2 (?) }\end{array}$ & $\begin{array}{l}\text { Zoea3,Zoea4,Zoea5 } \\
\text { Zoea3,Zoea4,Zoea5 }\end{array}$ & $\begin{array}{l}\text { Zoea6,Zoea7,Zoea8 } \\
\text { Zoea6,Zoea7,Zoea88 }\end{array}$ & $\begin{array}{l}\text { Zoea1-Zoea8 (?) } \\
\text { Zoea1-Zoea8 (?) }\end{array}$ \\
\hline 2nd PEREIOPOD & egg zoea like & egg megalop like & egg metanauplius & Zoea1,Zoea2 (?) & Zoea3,Zoea4 & Zoea1,Zoea2 (?) & Zoea3,Zoea4,Zoea5 & Zoea6,Zoea7,Zoea8 & Zoea1-Zoea8 (?) \\
\hline 3rd PEREIOPOD & egg zoea like & egg megalop like & egg metanauplius & Zoea1,Zoea2 (?) & Zoea3,Zoea4 & Zoea1,Zoea2 (?) & Zoea3,Zoea4,Zoea5 & Zoea6,Zoea7,Zoea8 & Zoea1-Zoea8 (?) \\
\hline 4th PEREIOPOD & egg zoea like & egg megalop like & egg metanauplius & Zoea1,Zoea2 (?) & Zoea3,Zoea4 & Zoea1,Zoea2 (?) & Zoea3,Zoea4,Zoea5 & Zoea6,Zoea7,Zoea8 & Zoea1-Zoea8 (?) \\
\hline 5th PEREIOPOD & egg zoea like & egg megalop like & egg metanauplius & Zoea1,Zoea2 (?) & Zoea3,Zoea4 & Zoea1,Zoea2 (?) & Zoea3,Zoea4,Zoea5 & Zoea6,Zoea7,Zoea8 & Zoea1-Zoea8 (?) \\
\hline CARAPACE & egg megalop like & egg megalop like & egg megalop like & Zoea1,Zoea2 (?) & Zoea1 (?) & Zoea1,Zoea2 (?) & Zoea3,Zoea4,Zoea5 & Zoea6,Zoea7,Zoea8 & Zoea1-Zoea8 (?) \\
\hline Segmented ABDOMEN & egg megalop like & egg megalop like & egg zoea like & Zoea1,Zoea2 (?) & Zoea1 (?) & Zoea1,Zoea2 (?) & Zoea1,Zoea2 (?) & Zoea1-Zoea5 (?) & Zoea1-Zoea8 (?) \\
\hline Bent/Fused TELSON & egg zoea like & egg megalop like & egg megalop like & Megalopa & Megalopa & Megalopa & Megalopa & Megalopa & Never \\
\hline
\end{tabular}

Note: - The order of presentation is based on the phylogenetic relationships among Brachyura family according to Tsang et al. (2014)

- *** describe the important transitions in the appearance of appendages.

- the interrogation mark (?) indicates the possibility of already having appendages in the eggs. 


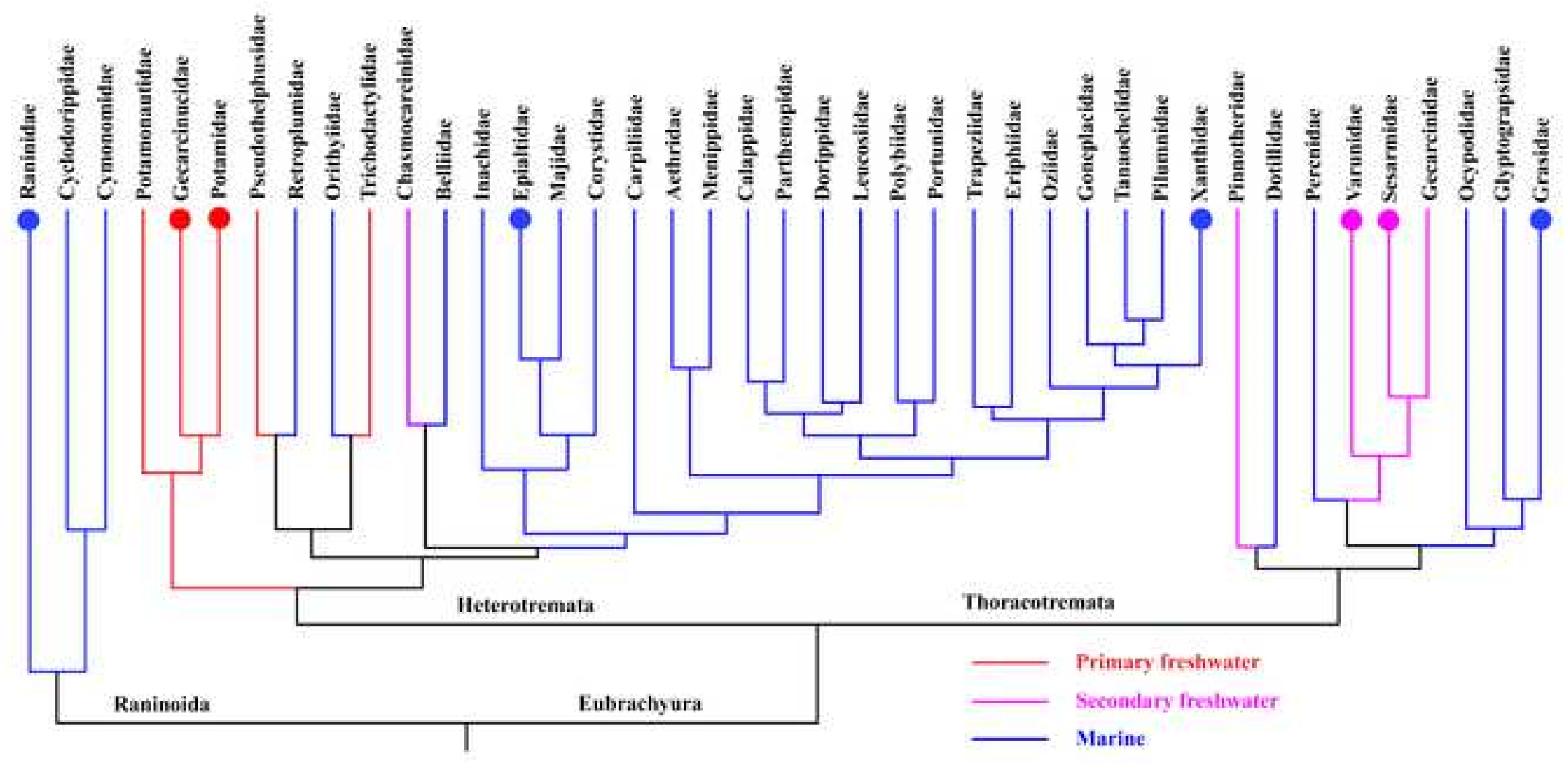



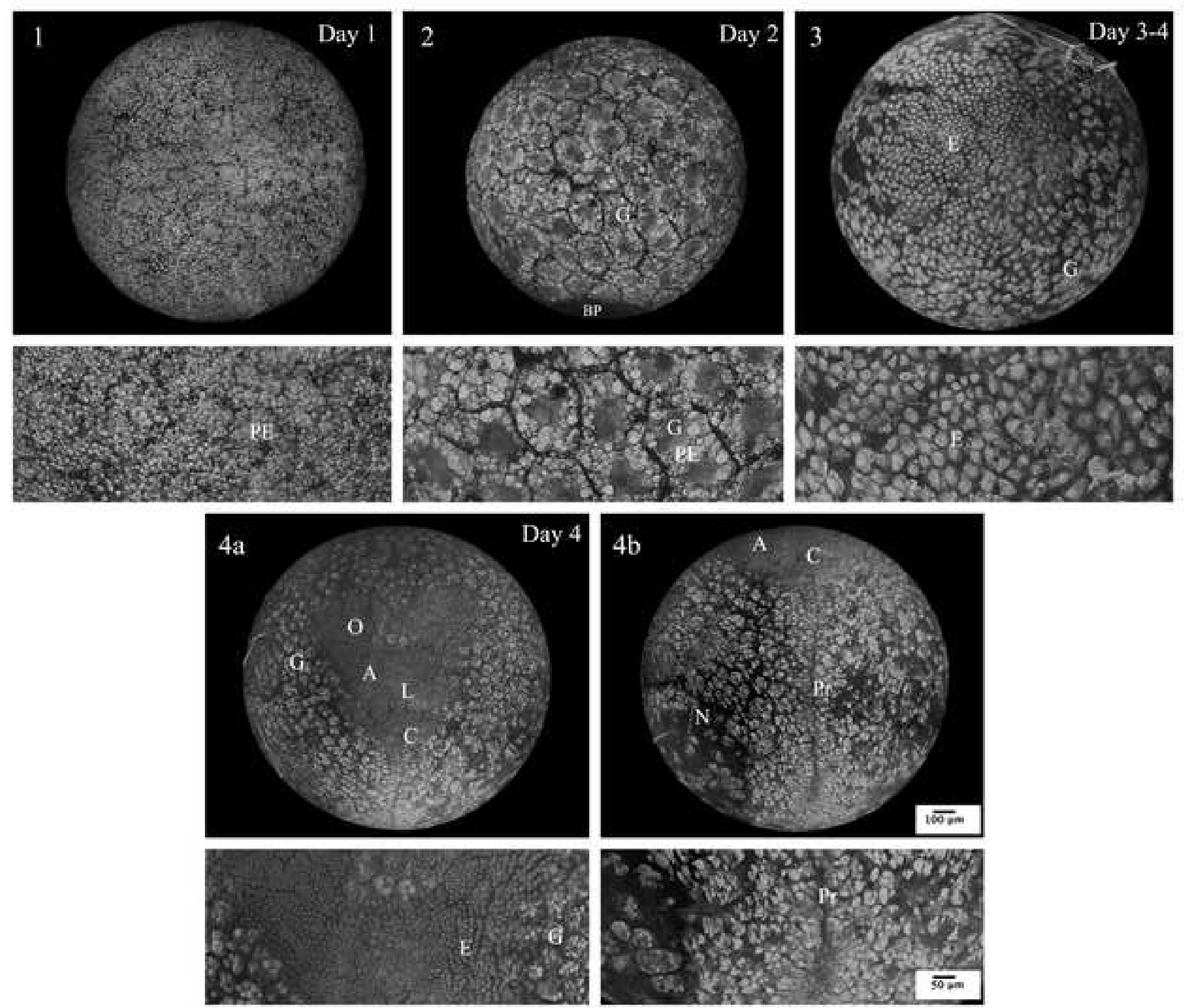

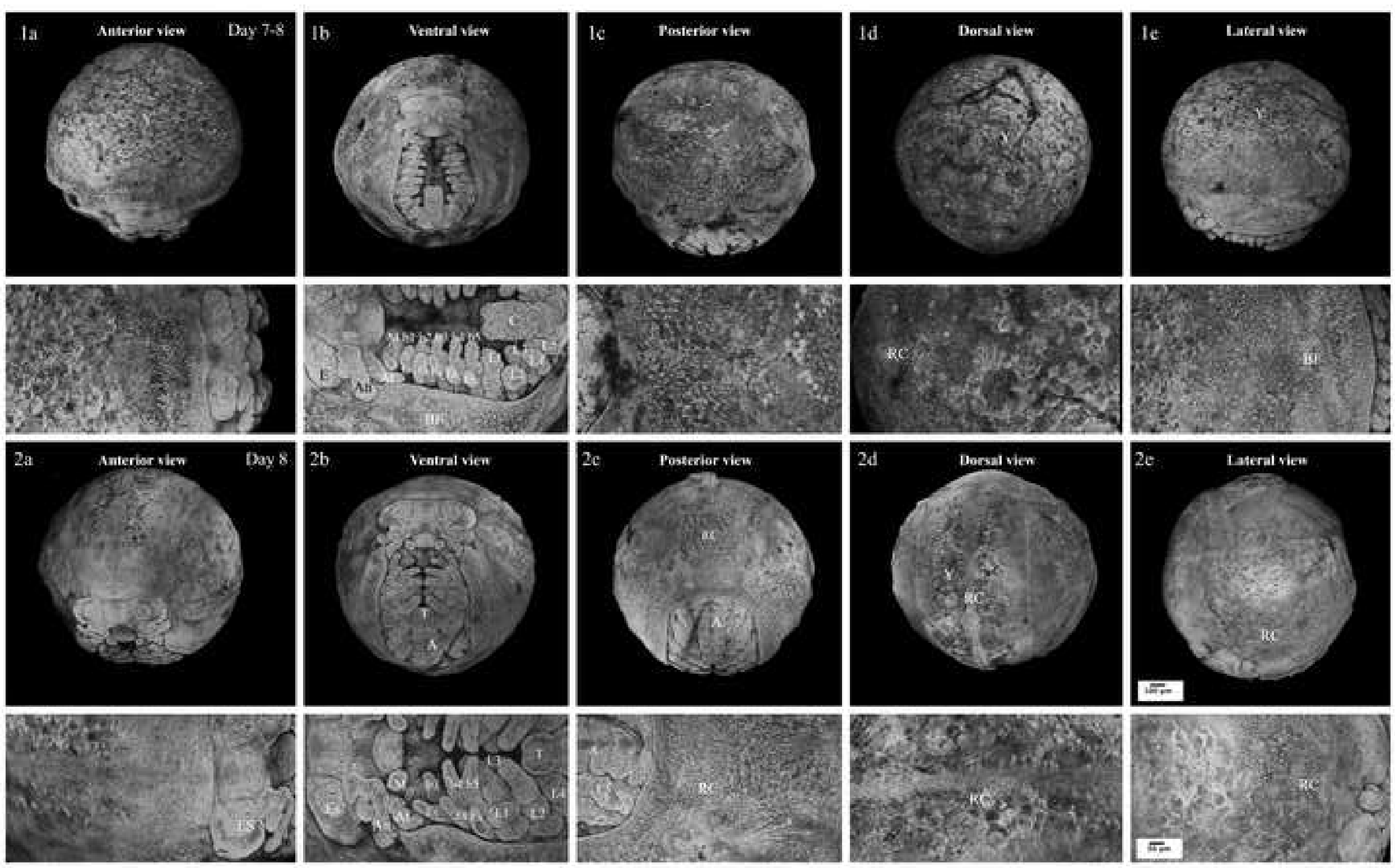


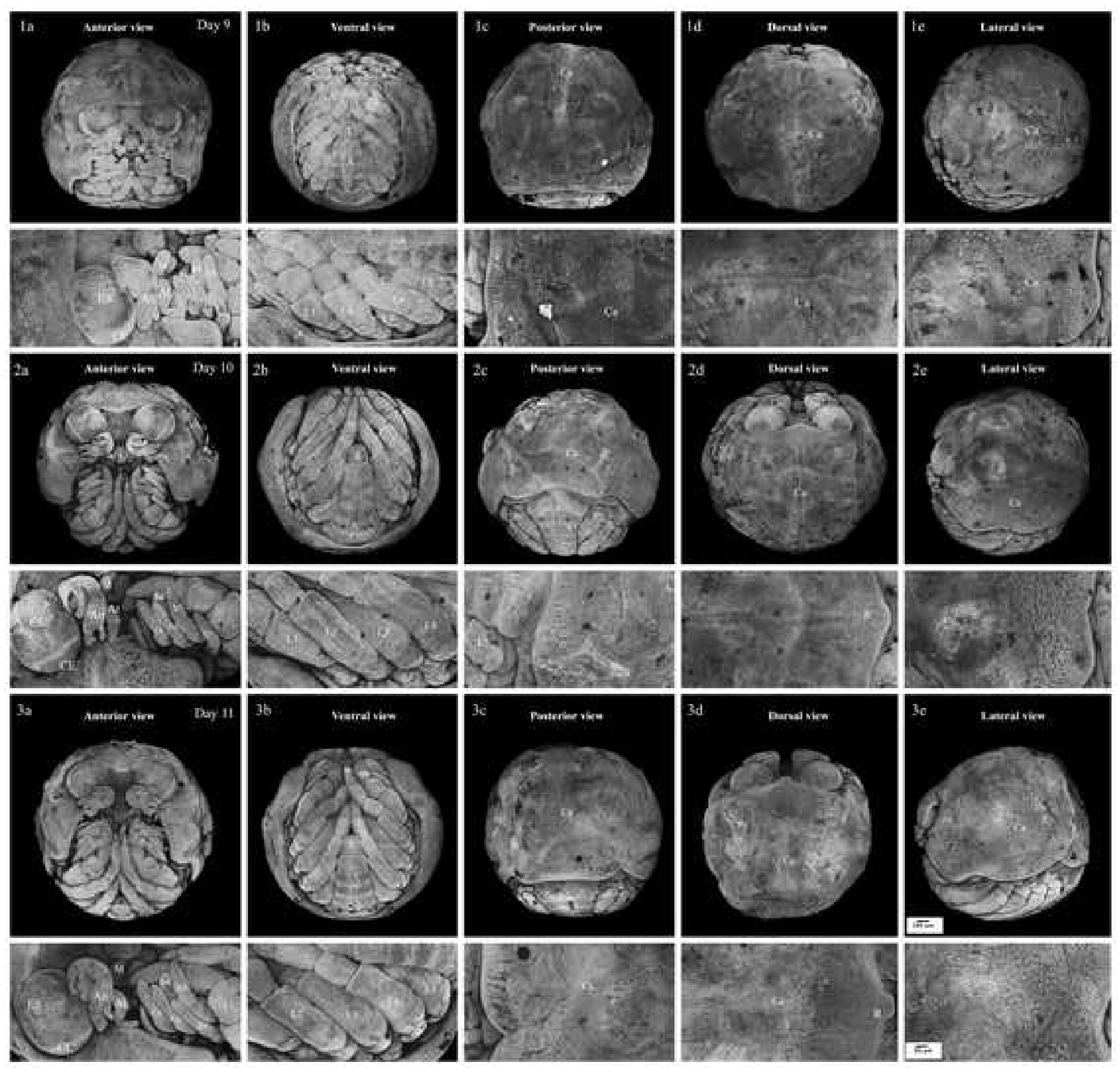



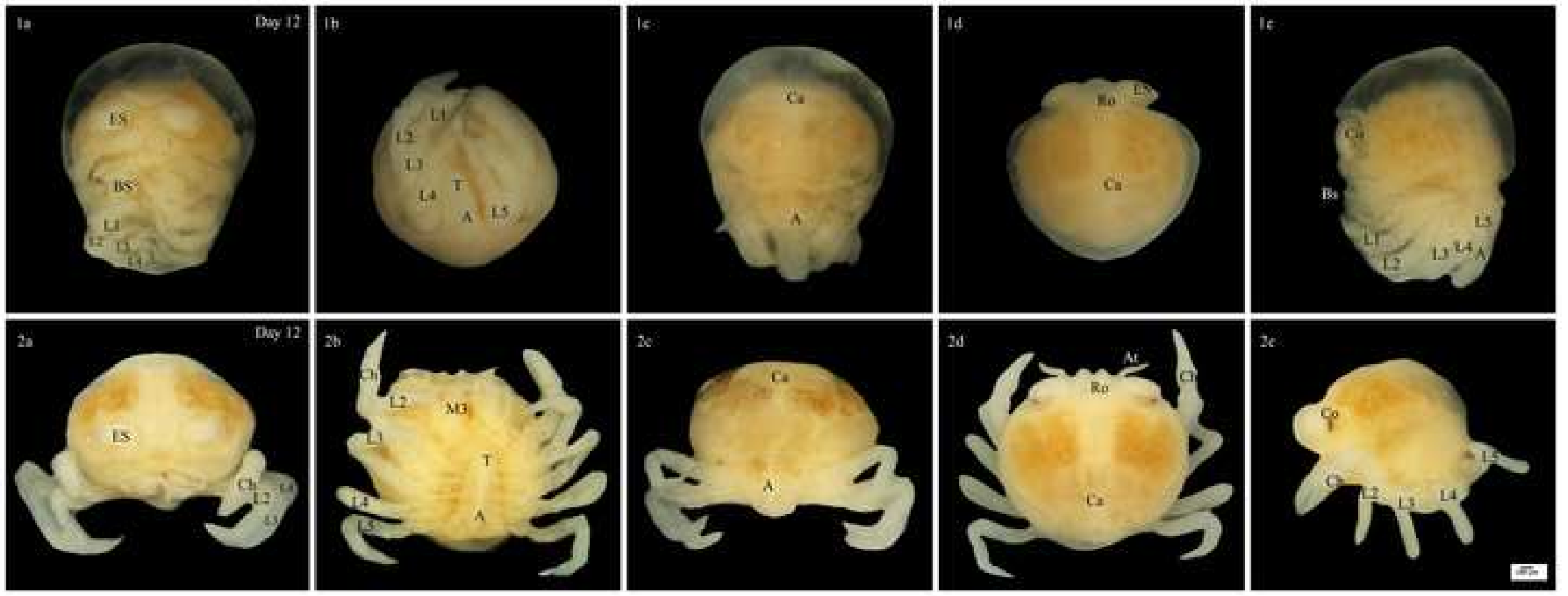